\title{
Morpheus Lander Testing Campaign
}

\author{
Jeremy J. Hart \\ NASA Johnson Space Center \\ 2101 NASA Parkway / EG6 \\ Houston TX, 77062 \\ 281-483-0001 \\ Jeremy.J.Hart@nasa.gov
}

\author{
Jennifer D. Mitchell \\ NASA Johnson Space Center \\ 2101 NASA Parkway / EA34 \\ Houston TX, 77062 \\ 281-483-8300 \\ Jennifer.D.Mitchell@nasa.gov
}

\begin{abstract}
NASA's Morpheus Project has developed and tested a prototype planetary lander capable of vertical takeoff and landing designed to serve as a testbed for advanced spacecraft technologies. The Morpheus vehicle has successfully performed a set of integrated vehicle test flights including hotfire and tether tests, ultimately culminating in an un-tethered "free-flight." This development and testing campaign was conducted on-site at the Johnson Space Center (JSC), less than one year after project start. Designed, developed, manufactured and operated in-house by engineers at JSC, the Morpheus Project represents an unprecedented departure from recent NASA programs and projects that traditionally require longer development lifecycles and testing at remote, dedicated testing facilities.
\end{abstract}

This paper documents the integrated testing campaign, including descriptions of test types (hot-fire, tether, and freeflight), test objectives, and the infrastructure of JSC testing facilities. A major focus of the paper will be the fast pace of the project, rapid prototyping, frequent testing, and lessons learned from this departure from the traditional engineering development process at NASA's Johnson Space Center.

\section{TABLE OF ConTENTS}

1. INTRODUCTION ..........................................1

2. SYSTEM DESCRIPTION.......................................3

3. DESCRIPTION OF MORPHEUS TEST TYPES .......3

4. Hot Fire TEST CAMPAIgNERROR! BOOKMARK NO 5. TETHER TEST CAMPAIGN . .5 6. INTEGRATED TEST CAMPAIGN FOLLOWING INNOVATION DAY .7

7. SUMMARY ......................................................99

BIOGRAPHY ........................................................9

\section{INTRODUCTION}

The Morpheus Project provides an integrated vertical test bed (VTB) platform for advancing multiple subsystem technologies. While technologies offer promise, capabilities offer potential solutions with application for future human exploration beyond Low Earth Orbit (LEO). Morpheus provides a bridge for evolving these technologies into capable systems that can be demonstrated and tested.

There are two key technologies that Morpheus is designed to integrate and demonstrate. The first is a liquid oxygen (LOX) / liquid methane propulsion system. The Morpheus LOX/methane propulsion system can provide a specific impulse during space flight of up to 321 seconds; it is cleanburning, non-toxic, and cryogenic, but space-storable. Additionally, for future space missions the methane could be produced in situ on Mars, and the oxygen is compatible on-board with life support systems or power generation. These attributes make LOX/methane an attractive propulsion technology for a lander of this scale.

The second technology is autonomous landing and hazard avoidance. When landing autonomously on any planetary or other surface, the vehicle must be able to determine a safe landing site that is free of large boulders, rocks, craters, or highly sloping surfaces. Morpheus is designed to carry sensors and software supporting tests that will demonstrate an integrated vehicle capability to perform these tasks.

Morpheus' predecessor, Pixel, was developed cooperatively with Armadillo Aerospace, and flown 17 times under tether and 3 times in free flight. Pixel was NASA's first vertical test bed to demonstrate LOX/methane propulsion. Armadillo operated the vehicle at their test facility near Dallas, Texas.

Morpheus design and development began in June 2010, primarily by an in-house team at NASA's Johnson Space Center. Like Pixel, Morpheus is a "quad" lander design with four tanks and a single engine. NASA JSC and Armadillo worked together initially on many aspects of the vehicle, including the 48" diameter aluminum tanks, but most of the vehicle subsystems were designed and developed by the NASA team. Additionally, NASA developed the operations center and all ground systems and ground support equipment for testing on-site at JSC.

\section{SYSTEM DESCRIPTION}

The VTB system elements include the flight test vehicle, ground systems, and operations.

\section{Vehicle}

The current Morpheus vehicle has a dry mass of $1800 \mathrm{lb}$, and a wet mass of $2800 \mathrm{lb}$ when loaded for a 50-second duration engine or flight test. The primary structure consists of welded aluminum box beams, machined parts, and a plate. The landing struts have honeycomb crush pads in the feet to attenuate landing loads. The avionics and guidance, navigation and control (GN\&C) components are located on a plate that spans the top deck of the primary structure. 
The propulsion system uses an impinging element-type engine design, with liquid oxygen and methane as the propellants. The engine is film-cooled, and operates as a blow-down system with an initial pressure of around 235 psi. The Morpheus engine is a $4300 \mathrm{lbf}$ engine with two orthogonal electromechanical actuators (EMAs) that gimbal the engine to provide lateral motion control, as well as pitch and yaw attitude control. Roll control is provided by cold gas jets that use the pressurized helium in the propellant tanks. Control of ascent and descent rates is provided by varying the engine throttle setting. The engine was tested at Armadillo prior to integration with Morpheus.

The propellant tanks are made of welded 5059 aluminum hemispheres. Armadillo welded the tanks, and NASA integrated them with Morpheus. Additionally, nondestructive evaluation of the tanks (x-ray of the welds, ultrasonic inspection of the tank hemispheres) was performed at NASA JSC during multiple stages of tank assembly. One tank was used for a burst test, one for a pressure cycle test, and the other four tanks were proof tested prior to vehicle integration.

The vehicle avionics and power subsystems include the flight computer, data recording, instrumentation, communications, cameras, and power. The flight computer is an AITech S900 CompactPCI board with a PowerPC 750 processor. Up to $16 \mathrm{~GB}$ of data can be stored on board. Data buses include RS-232, RS-422, Ethernet, and MIL-STD1553. Multiple channels of analog and digital inputs are used for both operational instrumentation and developmental flight instrumentation. Vehicle instrumentation includes temperature sensors, pressure transducers, tri-axial accelerometers, and strain gauges. A spread spectrum frequency band is used for wireless communications between the ground operators and the vehicle. Two on-board cameras provide views of the engine firing during testing. Eight lithium polymer batteries provide vehicle power.

The GN\&C sensor suite includes a Javad GPS receiver, an International Space Station (ISS) version of Honeywell's Space Integrated GPS/INS (SIGI), a Litton LN-200 Inertial Measurement Unit (IMU), and an Acuity laser altimeter. The vehicle is able to determine position to less than one meter, velocity to less than three $\mathrm{cm} / \mathrm{second}$, and attitude knowledge $<0.05$ degrees.

The vehicle software is architected around Goddard Space Flight Center's (GSFC) Core Flight Software (CFS). CFS was designed by GSFC to be a set of reusable software modules in a framework that can be adapted to a number of different space applications. Morpheus built on CFS by adding custom application code unique to the Morpheus vehicle and mission design.

\section{Ground Systems}

The VTB flight complex (VFC) includes two 20' x 20' concrete launch and landing pads located on a section of the
JSC antenna range near an old Apollo-era antenna tower. The closest occupied building is 2000 feet away.

The control center for on-site testing at JSC is a small building also located about 2000 feet from the launch area. JSC's "Building 18" is a small 2-story building formerly used for rooftop GPS testing and storage. One of the upstairs rooms has a window that looks directly out onto the launch area, making it highly suitable for the operations "front room," configured with three rows of computer tables for operator workstations. An adjacent room serves as the "back room” for support personnel.

The operator workstations use GSFC's Integrated Test and Operations System (ITOS) ground software. Like CFS, ITOS was developed as ground control and display software for GSFC space vehicles and has been made available to other projects at NASA. ITOS is individually configured to display vehicle telemetry and information unique to each operator position.

The mission telemetry, voice loops, and video can be streamed from the testing control center to JSC's Mission Control Center (MCC) over dedicated wireless and wired networks. From there, the data and video can be made available to both internal and external networks.

The flight termination system begins with two motorized valves that can be used to shut off flow of liquid oxygen and methane to the engine. If either valve is closed, the engine thrust will terminate. The motorized valves are completely independent from the rest of the vehicle systems and commanded using separate Ultra High Frequency (UHF) radios. The commands to initiate flight termination are sent from a control unit located in the operations center during any live engine testing.

Ground systems also include propulsion ground support equipment (GSE). The consumables required for an engine test include liquid oxygen, liquefied natural gas, helium, liquid nitrogen, and gaseous nitrogen. As described previously, LOX and methane are the primary vehicle propellants. For ground testing, the team uses cheaper liquefied natural gas (LNG) instead of methane with a negligible reduction in engine performance. Helium is used to pressurize the tanks. Liquid nitrogen is used pre-flight to provide cooling to the vehicle avionics. Gaseous nitrogen is used post-test to purge the tanks of LOX and methane or LNG before the vehicle is rolled back into the hangar.

All of these commodities are already available and regularly refilled on-site at JSC for other purposes, with the exception of LNG. Despite its widespread use for home heating, not many options were available for delivery of LNG to JSC. A Texas company called Clean Energy agreed to rent a trailer with two dewars to JSC and to deliver it filled for test days. On some occasions, JSC personnel have driven the trailer to Clean Energy's facility to obtain LNG when the project's test schedule did not accommodate Clean Energy's personnel availability. 
The power GSE is a portable ground power cart that is used to supply power to the vehicle until the test procedures call for a switch to vehicle power. The ground power cart uses heavy duty batteries and can provide up to 72 amp-hours of power for pre- and post-test activities. The ground power cart can be recharged overnight.

The mechanical GSE includes a rented crane for tethered or hot fire / hold-down testing. For tethered tests, an energy absorber is placed between the vehicle and the crane boom arm. The energy absorber is an aluminum piston and cylinder with cardboard honeycomb material that can attenuate up to $10,000 \mathrm{lb}$. This load attenuation is important if the vehicle is operating under the tether and engine thrust needs to be terminated prematurely, causing the vehicle to drop.

Ground systems also include a variety of transportation assets, provided primarily by JSC Center Operations. A forklift is used to transport the vehicle from the JSC on-site building that is used as a hangar (building 220) and the VFC. Other vehicles are used to transport the dewars of LOX and methane.

\section{Operations}

The final element of the Morpheus system is Operations. Eight primary operator positions are staffed by team members: test conductor (TC), operator (OPS), propulsion (PROP), avionics, power and software (APS), GN\&C (NAV), flight manager (FLT), and two range safety officers (RSO-1 and RSO-2). Each position is certified through specific training.

Certification is also required for three pad crew (PAD) positions. PAD-1 is the pad crew leader, responsible for communicating directly with the test conductor during operations and ensuring each procedural step is executed at the pad. PAD-2 and PAD-3 provide support to PAD-1, and conduct all handling of cryogenic fluids and most other consumables.

On test days, many other JSC and Morpheus team personnel serve in various functions. JSC riggers support vehicle transportation and crane operations. Support personnel for each subsystem monitor data or help out during testing in the "back room" of the control center. Other team members stay on standby for troubleshooting if problems arise.

\section{DESCRIPTION OF MORPHEUS TEST TyPES}

Morpheus testing includes three major types of integrated tests: hot-fire, tether, and free-flight. Between April 2011 and August 2011, the Morpheus team has completed 3 hotfire tests and 6 tether tests. Free-flight tests have been completed on Morpheus' predecessor called Pixel and are planned for the Morpheus vehicle in early 2012 following a series of hardware upgrades.

Hot-Fire Testing
During hot-fire testing the vehicle is completely restrained from movement and the primary focus is to test the LOX/methane propulsion system. In this configuration a crane is used to suspend the vehicle above the ground to provide clearance for the vehicle exhaust plume. The vehicle is also constrained from below using straps anchored to the ground that prevent vertical and lateral vehicle motion.

Figure 1 shows the vehicle during test in the hot-fire configuration. The vehicle is suspended approximately 20' above a concrete pad by a crane outfitted with shielding to prevent damage from flames or debris during the test firing. Additional restraints are attached below the vehicle made of nylon overwrapped with fireproof insulation. The lower straps are tensioned using metal turnbuckles that are then anchored into the concrete pad. This figure represents the final configuration during test firing. For initial power-up, checkout, and propellant loading the vehicle remains on the ground. The final lift is completed just prior to helium pressurization and test firing.

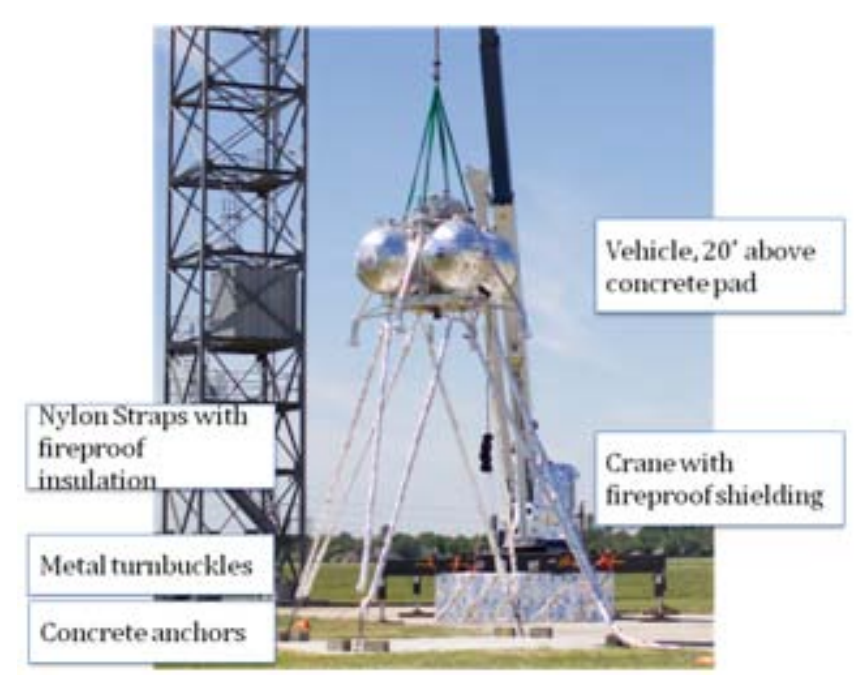

The objectives for hot-fire tests include demonstration of the igniter, engine ignition, performance at varied throttle settings and burn duration tests. The Morpheus project test approach is to limit tests on a test stand and quickly transition to the vehicle tests. Preliminary tests are conducted on By testing on the vehicle we can optimize engine performance for the actual vehicle feed system instead of the test stand system. Also, this allows tests such as gimbal sweeps to evaluate the integrated performance of the actuators under load. The majority of engine characterization is conducted on the vehicle and this, in effect, makes the hot-fire configuration the primary engine test stand for the Morpheus project.

\section{Tether Testing}

For tether tests the vehicle is suspended from a crane as shown in figure 2 to enable testing of the propulsion and integrated GN\&C without the risk of a vehicle departure or 
crash. The goal of these tests is to translate 5' vertically and then hover in place for a pre-programmed duration. Upon successful completion of the hover the vehicle descends and "lands" at the end of the tether.

Due to the potential dynamic loads during tethered flight, a substantially larger 120 -ton crane is used for this testing. As in hot-fire tests, an energy absorber is also used to reduce the loads on both the crane and Morpheus vehicle and help prevent damage to either asset. The energy absorber consists of a metal tub filled with sections of cardboard with a honeycomb cross-section. The cardboard sections dissipate dynamic loads when crushed and have specifically designed cutouts to provide the desired load attenuation characteristics. Below the energy absorber is a length of tether sufficiently long to allow 5' of vertical translation with margin for overshoot and altitude uncertainty. This tether is outfitted with a bungee cord to bunch the tether when slack and prevent it from draping and snagging on the vehicle. Suspending the vehicle 5' above the pad prevents the vehicle impacting the ground if a contingency engine shutdown is required. Finally, when the vehicle is lifted into place before testing it is held in place by a light-weight nylon hold-down cord to prevent motion prior to ignition. The rocket plume quickly melts the hold-down cord, allowing the vehicle to translate.

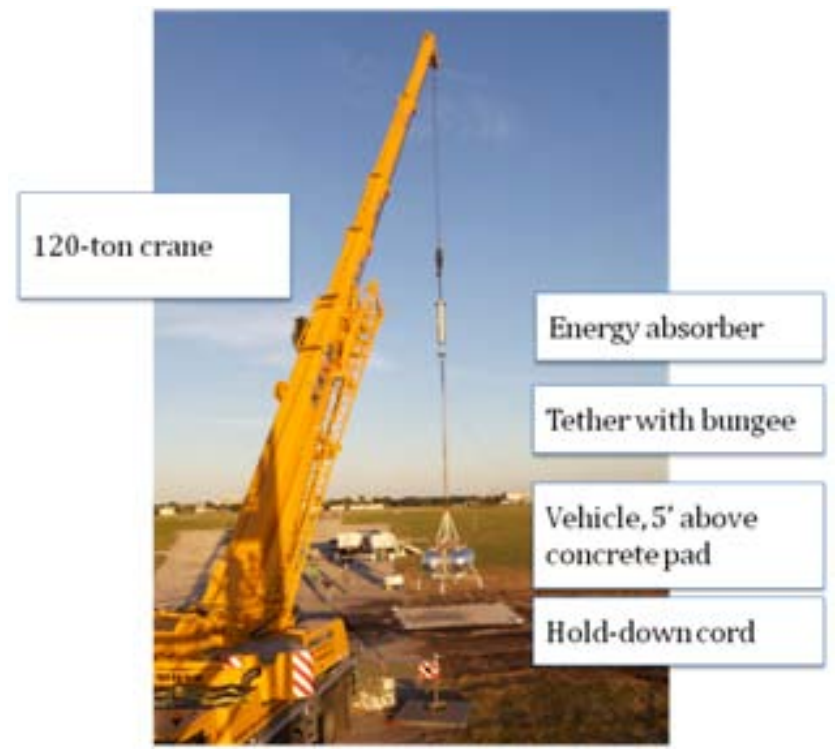

Tether testing provides the first opportunity to perform integrated testing of the Morpheus vehicle with closed-loop GN\&C. The primary objective of tether testing is to demonstrate 6 degree-of-freedom (DOF) GN\&C for vertical translation, hover and simulated landing operations. An additional objective is to understand the integrated performance of avionics, propulsion, and GN\&C. Tether testing allows rapid refinement of this integrated performance without risk of a vehicle crash.

\section{Free-Flight Testing}

Morpheus "free-flights" test the complete Morpheus system without the additional safeguards provided during tether. A variety of free-flight trajectories can be flown to incrementally build up to a fully functional Morpheus lander capable of flying planetary landing trajectories.

\section{Hot FiRE TEST CAMPAIgN}

During the Morpheus 1.0 test campaign, a series of three Hot-Fire tests were conducted to test and refine propulsion system performance. This was also the first opportunity to test vehicle hardware and software together. Due to the fast pace of development these test were also used as verification tests for numerous software routines. This section summarizes the initial set of hot-fire tests that are summarized in Table 1.

\section{Hot-Fire 0 (HFO)}

The first Morpheus hot-fire test was conducted on April $12^{\text {th }}, 2011$, and was intended to test the engine igniter and initial ignition. However, the propellant pressures at the igniter were insufficient for each of the six attempts to light the igniter. During the sixth attempt a small methane leak was ignited causing scorching of some tank insulation. At that point the test was terminated and all test objectives were deferred to Hot-Fire 1. HF0 revealed that the helium regulator used to supply helium to pressurize the vehicle tanks was insufficiently sized causing vehicle pressurization to take much longer than planned.

\section{Hot-Fire 1 (HF1)}

The team identified and fixed the HF0 issues in just two days and was ready to attempt the next test on April $14^{\text {th }}$. The helium regulator was replaced for one with greater capacity and the engine was modified to shorten and better insulate the propellant lines leading to the igniter.

During this test the igniter successfully lit on the first two attempts, completing that test objective. Main engine ignition was unsuccessful until the fifth attempt when the propellant lead was able to identify the proper startup conditions for ignition. A software script was designed to automatically terminate the burn 5 seconds after ignition, however that logic did not function properly. The manual backup commanding process was not immediately available, so the engine burned for 46 seconds before it was shut down manually. No engine damage resulted from the additional burn time and the team proceeded with the testing better prepared to manually terminate the burn quickly.

Two additional ignition tests of approximately 10-second duration were successfully conducted using the manual shutdown. Finally, a 30-second burn tested engine temperatures during a longer duration burn, completing the desired test matrix with all test objectives successfully met. The only major issue was the failure of the software script designed to automatically shutdown the engine. 


\section{Hot-Fire 2 (HF2)}

The next in the series of hot-fire tests was conducted on April $19^{\text {th }}, 2011$. The objectives of this test were to demonstrate the corrected software script, collect engine data during throttle and gimbal sweeps, demonstrate the handoff from startup to GN\&C software control, and exercise the Flight Termination System (FTS) valves. Five separate test runs tested one primary objective per run. Figure 3 shows an example of the engine testing during HF2.

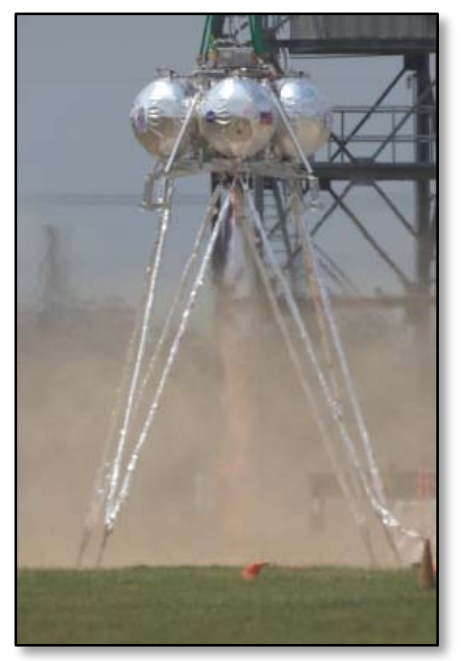

The first three test runs were completed successfully without any issues. The engine gimbals were actuated under thrust loading conditions for the first time during the third test run. During the fourth run the handover to GN\&C resulted in immediate shutdown of the engine as a result of an internal shutdown timer that was set during the first run of the day. Because this GN\&C software timer could not be reset at the pad, it was not possible to successfully execute the handover to GN\&C without immediate engine shutdown.

The next test run reverted to the non-GN\&C scripts and tested the FTS valves. The initial attempt did not result in proper engine ignition conditions due to the startup sequence being executed incorrectly, and this was remedied on the next attempt. During the final run of the day the engine was successfully terminated using the auxiliary valves powered by the independent FTS system. There was some small amount of engine damage due to excessive heating, as observed by a minor yellow flash observed in the engine plume.

\section{Hot-Fire Test Summary}

The Morpheus team completed the entire series of hot-fire tests in 8 days and successfully demonstrated all test objectives except for handover to GN\&C. There were issues identified in GSE (helium regulator), propulsion (engine plumbing issue that prevented the igniter from lighting during HF0), and software (engine scripts failed to shutdown properly). All issues were quickly resolved by the team and tested in subsequent tests. The team demonstrated adequate flexibility to work around these problems and complete the tests. Overall, these very successful tests provided the team with valuable vehicle operations experience and confidence to proceed with tether testing.

\section{Tether Test CAMPAign}

Tether tests immediately followed the Hot-Fire tests. A series of five tests was conducted between April $25^{\text {th }}$ and June $1^{\text {st }}$, 2011, with the primary objective to demonstrate stable 6-DOF GN\&C. The schedule of the first four tests was driven by a demonstration flight planned for the JSC Innovation Day event on May $4^{\text {th }}$. The pace of team activities quickened and test plans were reworked and finalized up to and on the test day.

\section{Tether Test 1 (TT1)}

Since tether tests focused on GN\&C, the initial portion of TT1 was dedicated to testing the GN\&C handover logic. The initial run testing the GN\&C handover was performed with a thrust-to-weight ratio (T/W) of less than one to prevent vehicle translation. This run was completed successfully with an 8-second engine burn terminated by the landing software "touchdown" indication.

A nominal tether test with a 20-second hover duration was planned to follow the initial run. However, due to a procedural oversight only one of the two batteries used to power Morpheus during flight was powered on. The battery voltage of the active battery quickly dropped to zero just before kicking off the nominal tether run. This resulted in total loss of vehicle power and telemetry and ended testing for the day. Fortunately, the vehicle has an auxiliary set of independently powered vent valves enabling depressurization of the vehicle without primary power.

\section{Tether Test 2 (TT2)}

The team attempted the nominal tether test again two days later on April 27 $7^{\text {th }}$. Since the power issue experienced during TT1 was a procedural oversight, no vehicle modifications were necessary prior to this test. However, last-minute modifications made to the vehicle rigging and the bungee used to prevent the tether from draping on the vehicle proved to be an issue.

Immediately upon engine ignition, an H-bridge circuit controlling the throttle valve failed causing the throttle valve to remain fully open ( $100 \%$ throttle). The vehicle rapidly ascended and an asymmetric bungee arrangement caused a pitching moment. When the ignition sequence was complete and control was handed over to GN\&C the vehicle was already in a presumably unrecoverable trajectory. To make matters worse, the GN\&C system also contained an incorrect coordinate frame due to an incomplete vendor specification of the Inertial Measurement Unit resulting in a 
90-degree clocking error. As a result, the GN\&C attempts to stabilize the vehicle motion were incorrect and futile. Figure 4 shows a snapshot of the vehicle motion during TT2.

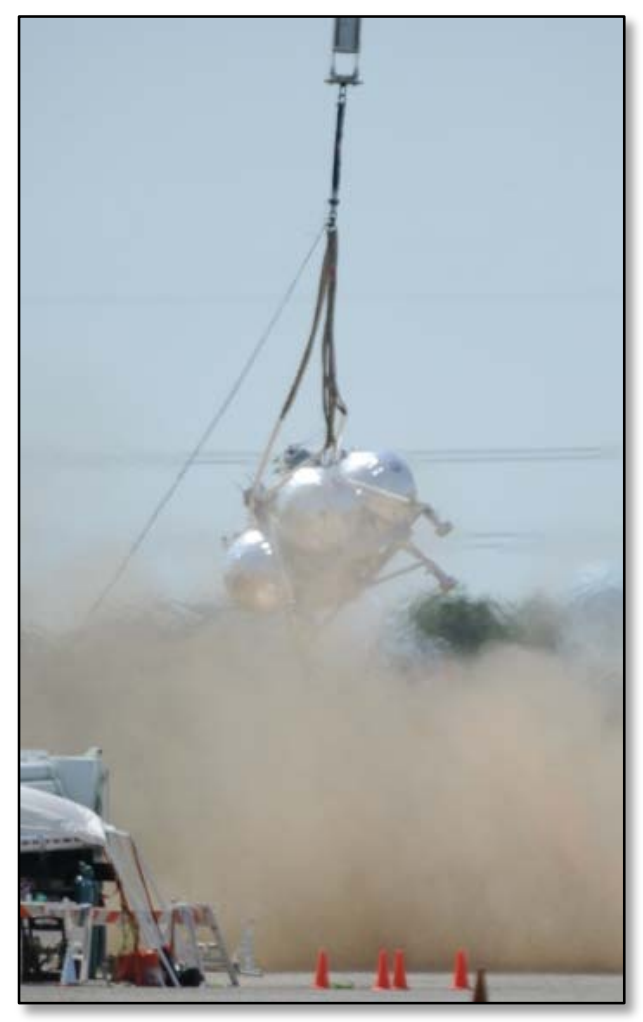

This uncontrolled motion continued despite on-board software and ground commands for soft and hard abort engine shutdown. These primary methods for engine shutdown all rely on the throttle valve, which had failed to full open. After 13 seconds of erratic flight the thrust was finally terminated when the wired FTS system was manually activated. Since the vehicle was tethered to the crane, no vehicle damage resulted from this test.

Although unsuccessful, this test identified a few key vehicle issues. The initial failure of the throttle valve was later attributed to the addition of diodes intended to prevent current flow back into the flight batteries that were not in the heritage Pixel electronics design. These diodes prevented the batteries from acting as capacitors to dissipate current build-up within the electronics. Without the capacitance effect of the batteries, the current build-up damaged the throttle valve H-bridge. Following this test the diodes were removed and a capacitor was added to help prevent future issues with current build-up.

The asymmetric bungee configuration that contributed to the dynamic vehicle motion was remedied for the next test. The bungee was intended to prevent slack tether on the vehicle becoming snagged or damaging hardware. Pre-test haste had led to insufficient attention being paid to the bungee configuration and the torque it would apply to the vehicle.

Finally, the frame error in the SIGI IMU used by Morpheus could have been caught in other integrated testing, such as a gimbal polarity test. However, the issue did not manifest itself in static tests such as gyroscopic compassing for heading initialization. This is an example of the streamlined test approach not catching an error until integrated testing.

Despite the dramatic and uncontrolled motion seen in TT2, this test resulted in identification of the key issues mentioned above without any vehicle or property damage.

\section{Tether Test 3 (TT3)}

All issues encountered in TT2 were addressed and resolved prior to the next tether test conducted on May $3^{\text {rd }}, 2011$. The team had recovered from TT2 and was prepared to test again in less than a week.

The objectives for TT3 were identical to TT2 except the planned hover duration was increased from 20 to 30 seconds. This test was much more successful than TT2, as the vehicle demonstrated vertical translation and transitioned to stable, hovering flight, albeit with some vertical oscillations due to GN\&C scheduler lag in throttle commands. Figure 5 shows the vehicle hovering above the landing pad during TT3.

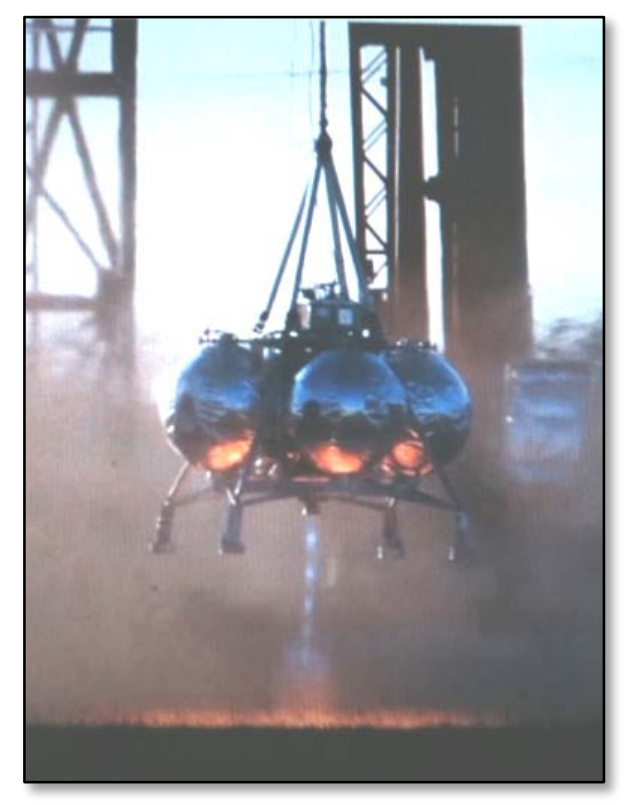

Despite the vertical oscillation, the test was proceeding towards its full hover duration until a load cell data cable snagged on the top of the vehicle, causing a pitching moment that resulted in a attitude rate limit violation that triggered the on-board soft abort logic. The vehicle slowly descended until the landing indication resulted in engine shutdown after a total run time of 20 seconds instead of the intended 30 seconds.

Even with the GN\&C scheduler issue and snagged cable, TT3 represented a significant improvement over the TT2 results. In particular, this test gave the team confidence to conduct a test for the public at the JSC Innovation Day event the following day.

Tether Test 4 (TT4) 
Since this test occurred only one day after TT3 no major technical improvements were made. Only two minor test modifications were made: the load cell cable was re-routed to prevent snagging on the vehicle, and the target hover time was increased to 40 seconds in order to use this test as a long duration test firing.

This test exhibited similar throttle behavior as in TT3 causing altitude control issues that led to attitude rates exceeding the soft abort limit, again resulting in early descent to the bottom of the tether. However, this time the landing logic did not trigger and a ground commanded shutdown was issued, terminating the test run at 29 seconds. The demonstration was well attended and received by the JSC and local community.

\section{INTEGRATED TEST CAMPAIGN FOLLOWING INNOVATION DAY}

After the Innovation Day demonstration on May $4^{\text {th }}$, the priority shifted to refining the design and verifying capability necessary to perform free-flight testing. The primary remaining technical challenges were to improve closed-loop GN\&C performance, characterize liftoff conditions, and verify the secondary channel of the FTS system, all of which were addressed by the next series of tests.

\section{Tether Test 5 (TT5)}

Immediately following the Innovation Day demonstration the team spent several weeks reviewing hot-fire and tether test data and working on design improvements, including GN\&C software modifications to address the scheduler/throttle lag problem, a heading computation issue, and several other minor software items. Another change was the addition of an experimental payload called the TVS (NAME?), a piezoelectric valve designed for cryogenic space applications.

TT5 was conducted on June $1^{\text {st }}$, 2011, following the design review and completion of the recommended software changes. The plan and objectives for TT5 were identical to those of TT4 including the targeted hover time of 40 seconds. During this test the vehicle successfully completed a full duration run with nominal shutdown after 42 seconds. GN\&C performance was improved and the vehicle hovered throughout the test with only a minor wobble with a period of approximately 3.2 seconds. The propulsion system performed nominally and reached steady-state engine temperatures for the first time during Morpheus vehicle testing.

Despite being the most successful test to date, TT5 resulted in a non-vehicle test range issue that caused the team to stand down from testing for over a month. Following the test, a small grassfire caused by spalling concrete was not properly contained and grew to a large grassfire covering 29 acres of JSC property. The grassfire was finally contained when local fire departments were called in. While a mishap investigation board completed its findings, the test team stood down and implemented improved fire prevention and suppression approaches, including the creation and maintenance of a fire break around the VFC.

\section{Hot-Fire 3 (HF3), Attempt 1}

The next test was designed to provide information about vehicle liftoff by igniting and throttling-up the engine from the ground. Unlike previous hot-fire tests, the vehicle was restrained with chains attached to the concrete anchors as shown in Figure 6, and T/W $<1.0$, ensuring that the vehicle could not lift off the ground.

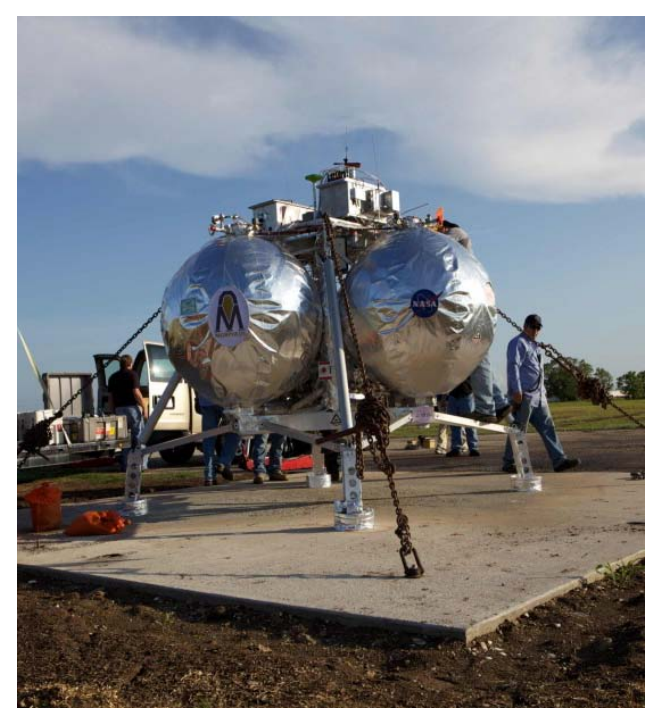

This test was also designed to verify the second FTS radio frequency operating in the VHF band. All previous tests had used one UHF radio signal to close both the LOX and LNG thrust termination valves. Adding a second independent radio and frequency provides the redundancy needed to allow free-flights at JSC, since closing either the LOX supply (via one radio) or the LNG supply (via the other radio) will terminate thrust.

During the initial power-up and checkout of the vehicle, high current values were observed that appeared to have a similar signature to the $\mathrm{H}$-bridge throttle failure experienced during TT2. The vehicle power was quickly turned off to prevent any additional damage to the vehicle avionics. However, it was later determined that the issue was not with the avionics, but instead due to electro-magnetic interference (EMI) from the new FTS radio antenna that was placed very close to unshielded wires on the top deck of the vehicle.

\section{Hot-Fire 3 (HF3), Attempt 2}

The next HF3 attempt was conducted one week later on July $27^{\text {th }}$ following troubleshooting and modifications to the FTS design to reduce EMI. Both radio antennae were moved to locations above the LOX tanks providing additional 
clearance from the avionics. Also, $10 \mathrm{~dB}$ attenuators were added to the vehicle-side radios to reduce the transmit power and additionally reduce EMI.

These modifications were successful in reducing the EMI to acceptable levels during testing. However, the new VHF channel continued to pose problems because of a lack of signal integrity. The radios were communicating, but the signal was intermittent with unacceptable performance for testing. The remainder of the test day was dedicated to isolating the VHF FTS including antenna locations both on and off the vehicle. Additional subsystem testing of the VHF FTS following HF3 was unsuccessful and the FTS system was returned to a single channel FTS system for Tether Test 6. Subsequent changes improved the FTS antenna design and switched the second FTS radio from VHF to an additional UHF frequency.

\section{Tether Test 6}

Tether test 6 was conducted on August 31 $1^{\text {st }}$, 2011, with the focus again to improve the closed-loop GN\&C performance. In response to the TT5 grassfire, the initial altitude of 5' with a target hover altitude of 10 ' was increased to 10 ' with a target hover altitude of 15' to help prevent excessive heating and spalling of the concrete pad. Other changes included the addition of automated chill-in logic for ignition, recalibration of the engine zero position, and the improved FTS antenna design.

During the test, the engine experienced a hard-start, a fuelrich ignition characterized by a loud 'bang' and large flame (Figure 7). This hard-start is believed to have created a longitudinal engine instability resulting in an engine burnthrough approximately 8-9 seconds after ignition (Figure 8). The burn-through sensor properly shutdown the engine in response to the failure and terminated thrust without additional vehicle damage.
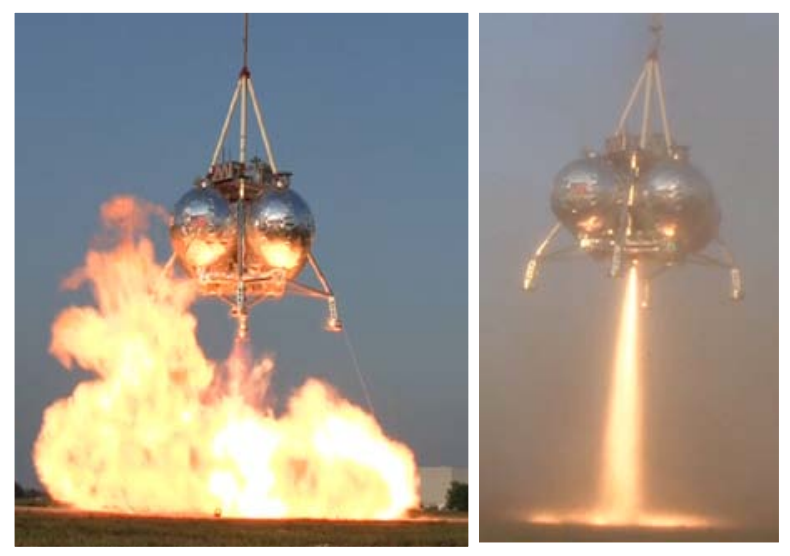

This engine instability was likely caused by ignition conditions produced by the automated chill-in logic. For future tests, this automated logic will be removed and the propulsion operator will handle ignition similar to all tests prior to TT6. Since the test flight was only 11 seconds in total duration, no GN\&C data was collected and the closedloop performance will be evaluated in future test events.

Each of the challenges experienced in the tests following JSC's Innovation Day provided valuable experience that improved the likelihood of success for future testing. By learning these lessons in Hot-Fire and Tether test configurations, the design has been improved without risk to the vehicle.

\section{SUMMARY}

The current project team has accomplished this test campaign in a relatively short time by developing lean processes, forming non-traditional partnerships with organizations contributing their own resources, and finding innovative approaches and solutions.

Primary activities in FY12 include implementation of LOXmethane propulsion and integration with the Autonomous Landing and Hazard Avoidance Technology (ALHAT) Project to perform high-energy flight demonstrations analogous to lunar surface landing trajectories. The Morpheus VTB provides the opportunity to test these precision landing and hazard avoidance technologies as well as subsystem concepts for GN\&C, propulsion, landing attenuation, power, and avionics, all in a flight-like dynamic environment.

\section{BIOGRAPHIES}

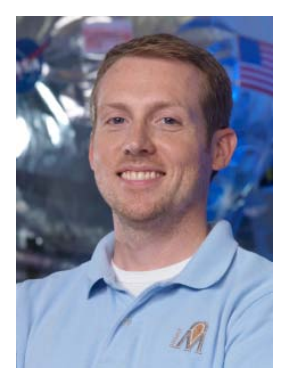

\section{Jeremy Hart}

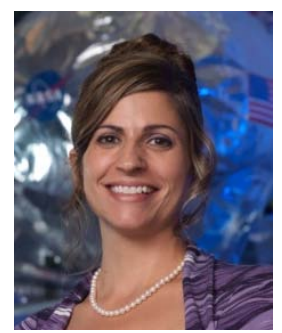

Jennifer D. Mitchell - Ms. Mitchell graduated from Texas A\&M University with a Bachelors Degree in Aerospace Engineering. She has worked at NASA JSC for 19 years in the Aeroscience and Flight Mechanics Division, working on guidance, navigation and control systems in both technical and management roles. She recently transferred to the Engineering Directorate's Systems Architecture and Integration Office. She currently serves as the systems engineering and integration lead for Project Morpheus, which is a prototype lunar lander vehicle that is operated on site at JSC in a terrestrial vertical test bed. The project has conducted 9 integrated vehicle tests on-site at JSC and is preparing for free flight-testing at JSC in the spring of 2012, with longer duration flights at Kennedy Space Center planned for the summer of 2012. 


\section{APPENDIX A: Test Summary}

\begin{tabular}{|c|c|c|c|c|c|c|}
\hline $\begin{array}{l}\text { Test } \\
\text { Name }\end{array}$ & Date & $\begin{array}{c}\text { Hardware, } \\
\text { GSE, FSW } \\
\text { changes } \\
\text { since last test }\end{array}$ & $\begin{array}{c}\text { Description / } \\
\text { Objectives }\end{array}$ & $\begin{array}{c}\text { Pass/ } \\
\text { Fail }\end{array}$ & $\begin{array}{l}\text { Burn } \\
\text { Time }\end{array}$ & Test Results and Notes \\
\hline HF0 & $4 / 12 / 2011$ & & $\begin{array}{l}\text { Igniter Tests } \\
\text { (6 attempts) }\end{array}$ & Fail & $\mathrm{n} / \mathrm{a}$ & $\begin{array}{l}\text { - Issues with Helium pressurization } \\
\text { - None successfu due to low pressure. } \\
\text { - Ignited Methane leak at -Y lower tank } \\
\text { boss }\end{array}$ \\
\hline \multirow[t]{4}{*}{ HF1 } & \multirow[t]{4}{*}{$4 / 14 / 2011$} & \multirow{4}{*}{$\begin{array}{l}\text { - Helium } \\
\text { Regulator } \\
\text { change } \\
\text { - Engine } \\
\text { plumbing } \\
\text { improvement } \\
\text { for better } \\
\text { chill-in }\end{array}$} & $\begin{array}{l}\text { Igniter Tests } \\
\text { ( } 2 \text { runs) }\end{array}$ & Pass & $\mathrm{n} / \mathrm{a}$ & 2 consecutive successful igniter tests. \\
\hline & & & $\begin{array}{l}\text { Ignition Tests } \\
\text { (4 attempts) }\end{array}$ & Fail & n/a & 4 failed ignition tests \\
\hline & & & $\begin{array}{l}\text { Ignition Tests } \\
\text { (3 runs) }\end{array}$ & Pass & $\begin{array}{l}46 \mathrm{~s} \\
13 \mathrm{~s} \\
14 \mathrm{~s}\end{array}$ & $\begin{array}{l}\text { FSW script failed to terminate properly } \\
\text { requiring manual termination }\end{array}$ \\
\hline & & & $\begin{array}{l}\text { Ignition Tests } \\
\text { (1 run) }\end{array}$ & Pass & $30 \mathrm{~s}$ & $\begin{array}{l}\text { FSW script failed to terminate properly } \\
\text { requiring manual termination }\end{array}$ \\
\hline \multirow[t]{6}{*}{ HF2 } & \multirow[t]{6}{*}{$4 / 19 / 2011$} & \multirow[t]{6}{*}{$\begin{array}{l}\text { Sofware } \\
\text { update to } \\
\text { allow } \\
\text { automatic } \\
\text { script } \\
\text { termination }\end{array}$} & $\begin{array}{l}\text { Ignition Tests } \\
\text { (same as } \\
\text { HF1, with } \\
\text { corrected SW } \\
\text { logic) }\end{array}$ & Pass & $7 \mathrm{~s}$ & Successful completion of SW sequence \\
\hline & & & $\begin{array}{l}\text { Burn duration } \\
\text { test, vary } \\
\text { throttle level }\end{array}$ & Pass & $22 \mathrm{~s}$ & Successful completion of SW sequence \\
\hline & & & $\begin{array}{l}\text { Burn } \\
\text { Duration test } \\
\text { with gimbal } \\
\text { sweep }\end{array}$ & Pass & $12 \mathrm{~s}$ & Successful completion of SW sequence \\
\hline & & & $\begin{array}{l}\text { GNC } \\
\text { Activation } \\
\text { Test }\end{array}$ & Fail & $\mathrm{n} / \mathrm{a}$ & $\begin{array}{l}\text { GNC activation failed due to expired } \\
\text { timer. }\end{array}$ \\
\hline & & & $\begin{array}{l}\text { Burn } \\
\text { Duration Test } \\
(100 \% \\
\text { throttle), FTS } \\
\text { activation }\end{array}$ & Fail & $\mathrm{n} / \mathrm{a}$ & $\begin{array}{l}\text { - Used ground scripts instead of GNC } \\
\text { activation. } \\
\text { - Failed to initiate because of failed TC } \\
\text { check. }\end{array}$ \\
\hline & & & \multirow{2}{*}{$\begin{array}{l}\text { Burn } \\
\text { Duration Test } \\
(100 \% \\
\text { throttle), FTS } \\
\text { activation } \\
\text { GNC } \\
\text { Activation } \\
\text { Test }\end{array}$} & \multirow[t]{2}{*}{$\begin{array}{l}\text { Pass } \\
\text { Pass }\end{array}$} & $13 \mathrm{~s}$ & \multirow[t]{2}{*}{$\begin{array}{l}\text { - Used ground scripts instead of GNC } \\
\text { activation. } \\
\text { - Minor yellow flash observed } \\
\text { - FTS termination valves (wired } \\
\text { activation) } \\
\text { Soft abort, Landing indication }\end{array}$} \\
\hline \multirow[t]{2}{*}{ TT1 } & $4 / 25 / 2011$ & $\begin{array}{l}\text { GNC } \\
\text { handover fix }\end{array}$ & & & $8 \mathrm{~s}$ & \\
\hline & & & $\begin{array}{l}\text { Nominal } \\
\text { Tether test } \\
(20 \mathrm{~s} \\
\text { Duration) } \\
\end{array}$ & N/A & & $\begin{array}{l}\text { - Did not attempt nominal hover due to } \\
\text { battery loss. } \\
\text { - Battery loss resulted in wired vent } \\
\text { valves to depressurize }\end{array}$ \\
\hline
\end{tabular}




\begin{tabular}{|c|c|c|c|c|c|c|}
\hline $\begin{array}{c}\text { Test } \\
\text { Name }\end{array}$ & Date & $\begin{array}{c}\text { Hardware, } \\
\text { GSE, FSW } \\
\text { changes } \\
\text { since last test }\end{array}$ & $\begin{array}{l}\text { Description / } \\
\text { Objectives }\end{array}$ & $\begin{array}{l}\text { Pass/ } \\
\text { Fail }\end{array}$ & $\begin{array}{l}\text { Burn } \\
\text { Time }\end{array}$ & Test Results and Notes \\
\hline TT2 & $4 / 27 / 2011$ & & $\begin{array}{l}\text { Nominal } \\
\text { Tether test } \\
\text { (20 s } \\
\text { duration) }\end{array}$ & Fail & $13 \mathrm{~s}$ & $\begin{array}{l}\text {-Stuck throttle and tether forces caused } \\
\text { dynamic uncontrolled motion } \\
\text { - SIGI frame issue } \\
\text { - Attempted Soft and Hard abort } \\
\text { commands (innefective due to failed } \\
\text { throttle valve electronics). } \\
\text { - Flight terminated via FTS } \\
\text { termination valves (wired activation) }\end{array}$ \\
\hline TT3 & $5 / 3 / 2011$ & $\begin{array}{l}\text { - Removed } \\
\text { diodes added } \\
\text { capacitor } \\
\text { - Used spare } \\
\text { H-bridge for } \\
\text { throttle } \\
\text { - SIGI frame } \\
\text { fix } \\
\text { - Modified } \\
\text { tether } \\
\text { configuration } \\
\text { - Wireless } \\
\text { FTS }\end{array}$ & $\begin{array}{l}\text { Nominal } \\
\text { Tether test } \\
\text { (30 s } \\
\text { duration) }\end{array}$ & Fail & $20 \mathrm{~s}$ & $\begin{array}{l}\text { - Scheduler issue cause throttle to drop } \\
\text { resulting in vehicle drop } \\
\text { - DFI cable snagged on vehicle causing } \\
\text { disturbance force. } \\
\text {-Violated attitude rates - initiated a soft } \\
\text { abort, terminated via landing indication }\end{array}$ \\
\hline TT4 & $5 / 4 / 2011$ & $\begin{array}{l}\text { Improved } \\
\text { DFI load cell } \\
\text { wire routing }\end{array}$ & $\begin{array}{l}\text { Nominal } \\
\text { Tether test } \\
\text { (40 s } \\
\text { duration) }\end{array}$ & Fail & $29 \mathrm{~s}$ & $\begin{array}{l}\text {-Violated attitude rates, initiating a soft } \\
\text { abort, terminated via ground hard abort } \\
\text { command } \\
\text { - Scheduler issue cause throttle to drop } \\
\text { resulting in vehicle drop }\end{array}$ \\
\hline TT5 & 6/1/2011 & $\begin{array}{l}\text { - GNC } \\
\text { scheduler and } \\
\text { Heading fixes } \\
\text { - Other minor } \\
\text { software } \\
\text { mods } \\
\text { - Added TVS } \\
\text { experiment }\end{array}$ & $\begin{array}{l}\text { Nominal } \\
\text { Tether test } \\
\text { (40 s } \\
\text { duration) }\end{array}$ & Pass & $42 \mathrm{~s}$ & $\begin{array}{l}\text { - Nominal engine shutdown after fully } \\
\text { duration test. } \\
\text { - Minor control 'wobble' with period of } \\
\text { 3.2 seconds observed. } \\
\text { - Failed to contain grassfire resulting in } \\
\text { local FD support. }\end{array}$ \\
\hline $\begin{array}{l}\text { HF3 } \\
\text { attem } \\
\text { pt } 1\end{array}$ & $7 / 20 / 2011$ & $\begin{array}{l}\text { - Change } \\
\text { actuator } \\
\text { commanding } \\
\text { to high- } \\
\text { frequency } \\
\text { PWM } \\
\text { electronics } \\
\text { - Added } \\
\text { engine } \\
\text { protection } \\
\text { limits and } \\
\text { burn-through } \\
\text { wire } \\
\text { - Added } \\
\text { second FTS } \\
\text { channel } \\
\text { (VHF) }\end{array}$ & $\begin{array}{l}\text { - Engine } \\
\text { Overpressure } \\
\text { test ( } 2 \text { sec, } \\
\text { then auto } \\
\text { shutdown) } \\
\text { - FTS test } \\
\text { (initiate FTS } \\
\text { at } 100 \% \\
\text { throttle, auto } \\
\text { shutdown at } 5 \\
\text { sec) }\end{array}$ & N/A & N/A & $\begin{array}{l}\text { Test halted due to high current } \\
\text { observed in several telemetry signals } \\
\text { (due to EMI from the new VHF FTS } \\
\text { radio) }\end{array}$ \\
\hline
\end{tabular}




\begin{tabular}{|c|c|c|c|c|c|c|}
\hline $\begin{array}{l}\text { Test } \\
\text { Name }\end{array}$ & Date & $\begin{array}{c}\text { Hardware, } \\
\text { GSE, FSW } \\
\text { changes } \\
\text { since last test }\end{array}$ & $\begin{array}{c}\text { Description / } \\
\text { Objectives }\end{array}$ & $\begin{array}{c}\text { Pass/ } \\
\text { Fail }\end{array}$ & $\begin{array}{l}\text { Burn } \\
\text { Time }\end{array}$ & Test Results and Notes \\
\hline $\begin{array}{l}\text { HF3 } \\
\text { attem } \\
\text { pt } 2\end{array}$ & 7/27/2011 & $\begin{array}{l}\text { - Relocated } \\
\text { FTS1 and } \\
\text { FTS2 } \\
\text { antennae to } \\
\text { above the } \\
\text { LOX tanks. } \\
\text { - Added } 10 \\
\text { dB } \\
\text { attenuators to } \\
\text { the flight-side } \\
\text { of both UHF } \\
\text { and VHF } \\
\text { channels } \\
\end{array}$ & $\begin{array}{l}\text { - Engine } \\
\text { Overpressure } \\
\text { test ( } 2 \mathrm{sec}, \\
\text { then auto } \\
\text { shutdown) } \\
\text { - FTS test } \\
\text { (initiate FTS } \\
\text { at } 100 \% \\
\text { throttle, auto } \\
\text { shutdown at } 5 \\
\text { sec) }\end{array}$ & N/A & N/A & $\begin{array}{l}\text { Test halted due to insufficient VHF } \\
\text { FTS communication link }\end{array}$ \\
\hline TT6 & 8/31/2011 & $\begin{array}{l}\text { - Vehicle start } \\
\text { position } \\
\text { raised from 5' } \\
\text { to } 10 \text { ' above } \\
\text { the tether pad } \\
\text { - Added } \\
\text { automated } \\
\text { chill-in logic } \\
\text { - Improved } \\
\text { engine } \\
\text { mounting } \\
\text { - Re- } \\
\text { calibrated } \\
\text { gimbal } \\
\text { alignment } \\
\text { - Reverted to } \\
\text { UHF-only } \\
\text { FTS and } \\
\text { added } \\
\text { antenna } \\
\text { ground plane }\end{array}$ & $\begin{array}{l}\text { Nominal } \\
\text { Tether test } \\
\text { (40 s } \\
\text { duration) }\end{array}$ & Fail & $11 \mathrm{~s}$ & $\begin{array}{l}\text { - Auto 'chill-in' logic for the first } 5 \\
\text { seconds (actual ignition to shutdown } \\
\text { was } 16 \mathrm{sec} \text { ) } \\
\text { - Burn-through wire resulting in soft } \\
\text { abort and engine shutdown on } \\
\text { touchdown indication. } \\
\text { - Ground shutdown was also } \\
\text { commanded, but after engine was } \\
\text { already shutdown }\end{array}$ \\
\hline
\end{tabular}

